\title{
Validity evidences of the Buying Impulsiveness Scale in the Brazilian Context
}

\author{
Sibele Dias de Aquino \\ Jean C. Natividade \\ Samuel Lincoln Bezerra Lins ${ }^{2}$ \\ ${ }^{1}$ Pontifícia Universidade Católica do Rio de Janeiro \\ ${ }^{2}$ Faculdade de Psicologia e de Ciências da Educação da Universidade do Porto
}

\begin{abstract}
The objective of this study was to obtain evidence of validity of an instrument to measure the tendency to buy impulsively. A version adapted to Brazil of a Buying Impulsiveness Scale was applied to 1296 Brazilians from all states of the federation, with a mean age of 35.8 years $(S D=12.8)$. The results indicated a scale with one-factor structure, just like the original instrument, with an adequate index of internal consistency. Positive correlations were found between impulse buying tendency, normative social influence, and traits of impulsiveness of the consumer. The instrument was also able to differentiate people who make shopping lists from those who do not do them, and people who prefer to go shopping alone from those who prefer to buy accompanied by someone else. The evidences found in the study provide support to the use of the instrument for the Brazilian context. Keywords: consumer behavior; impulsiveness; validity of the test; self-assessment scales
\end{abstract}

Evidências de Validade da Escala de Compra por Impulso para o Contexto Brasileiro

\begin{abstract}
Resumo
O objetivo deste estudo foi buscar evidências de validade de um instrumento para aferir a tendência de comprar impulsivamente. Aplicou-se uma versão adaptada para o Brasil de uma escala de compra por impulso em 1.296 brasileiros de todos os estados da federação, média de idade de 35,8 anos $(D P=12,8)$. Os resultados indicaram uma escala com estrutura unifatorial, tal como o instrumento original, com adequado índice de consistência interna. Foram encontradas correlações positivas entre a tendência de comprar por impulso, a influência social normativa e traços de impulsividade do consumidor. O instrumento também foi capaz de diferenciar pessoas que fazem lista de compras das que não fazem e pessoas que preferem ir às compras sozinhas das que preferem comprar acompanhadas. As evidências encontradas suportam o uso do instrumento para o contexto brasileiro. Palavras-chave: comportamento do consumidor, impulsividade, validade do teste, escalas de autoavaliação
\end{abstract}

Evidencias de Validez de Escala de Compras por Impulso en el Contexto Brasileño

\begin{abstract}
Resumen
El objetivo de este estudio fue buscar evidencias de validez de un instrumento para medir la tendencia de comprar impulsivamente. Se aplicó una versión adaptada para Brasil de una escala de compra por impulso en 1296 brasileños de todos los estados del país, con promedio de edad de 35,8 años (DP = 12,8). Los resultados indicaron una escala con estructura unifactorial, tal como el instrumento original, con adecuado índice de consistencia interna. Se encontraron correlaciones positiva entre tendencia de comprar por impulso, influencia social normativa y rasgos de impulsividad del consumidor. El instrumento también fue capaz de diferenciar personas que hacen lista de compras de las que no hacen, y personas que prefieren ir de compras solas de las que prefieren ir acompañadas. Las evidencias encontradas apoyan el uso del instrumento en el contexto brasileño. Palabras clave: comportamiento del consumidor; impulsividad; validez del test; escala de autoevaluación
\end{abstract}

When someone is about to buy something, several psychological processes are unleashed. One of the behaviors that can be observed as resulting from these processes is impulse buying (Sant'anna, 1989). Purchases that respond to an impulse are more frequent than the pre-calculated ones and go beyond what is considered as unplanned buying (Farina, Perez, \& Bastos, 2006; Podoshen \& Andrzejewski, 2012). Unplanned purchases happen when the consumer only acquires something in an unpremeditated way, responding to a feeling of urgency (Lopes, 2002). Impulse buying can be defined as a sudden will along with an intense emotional desire to buy immediately (Arnould, Price,
\& Zinkhan, 2004; Amos, Holmes, \& Keneson, 2014). According to Rook and Hoch (1985), impulse buying presents key elements that define it, namely, the spontaneous need to act; a feeling of unbalanced emotional state; reduced ability to perform cognitive assessments; occurrence of psychological conflict; and consumption without evaluation of consequences.

In the definitions of impulse buying there is a tendency in the authors to emphasize the spontaneity, the inconsequence and the emotional state of the individuals at the moment of purchase (e.g., Arnould et al., 2004; Lins \& Pereira, 2011; Youn \& Faber, 2000). For Rook and Fisher (1995), impulsive buying behavior 
is characterized by the "consumer's tendency to buy spontaneously, unreflectively, immediately, prompted by physical proximity to a desired product, dominated by emotional attraction to it, and absorbed by the promise of immediate gratification" (p. 306). This definition was adopted by the authors in constructing an instrument to measure impulse buying behaviors. In this study, we seek to find evidence of validity for the Buying Impulsiveness Scale of Rook and Fisher (1995), based on the definition adopted by them.

The Buying Impulsiveness Scale proposed by Rook and Fisher (1995) can be considered one of the first consistent proposals to measure impulse buying. The authors elaborated it with the objective of investigating the relationship between impulsiveness in purchases and the consumer's buying behavior. Participants in their study, in which the instrument was created, were exposed to a hypothetical situation in which they had to choose one of five response options characterized by different levels of impulse buying. The relationship between the impulsive buying trait and impulsive behavior was moderated by normative evaluations; consequently, one of the constructs with which impulse buying was related was social influence.

When Rook and Fisher (1995) developed the scale to measure the degree of impulse buying of individuals, they related this aspect to the perception of social adequacy of the buying behavior. The individual's belief that his buying behavior is socially adequate and acceptable was called normative influence. The consumer's behavior can, according to socially desirable parameters, leverage or inhibit the expectation of buying, motivating impulsivity in the purchase (Luo, 2005). The scale of Rook and Fisher (1995) attempts to assess buying impulsiveness on the basis of normative influences and also through a conative assessment, which is characterized by the promptness and reactivity of the individual to the purchase, indicating a predisposition to the consumer's action.

The buying process can also be understood as a typically social phenomenon and understood as a form of integration with the environment, assuming that the individual is directly influenced by the people who are part of his group (Garðarsdóttir \& Dittmar, 2012). For example, the mere presence of other people in a purchasing situation can influence the ultimate behavior of the consumer (Luo, 2005; Masouleh, Pazhang, \& Moradi, 2012).

Some studies present the relationship of impulsive buying with social influence, and social and personal norms (Mangleburg, Doney, \& Bristol, 2004; Taute \& McQuitty, 2004). Rook and Fisher (1995) found that negative normative evaluations mute impulse buying tendencies, that is, if the individual understands that their impulse to buy is in dissonance with the expectations of others, he will tend to submit and act according to the norm, increasing the likelihood that the purchase will not be materialized. The whole environmental context can influence the buying behavior and the presence of other people in a situation of consumption tends to have an important impact in the decision to make the purchase. When people think that impulse buying behavior is socially acceptable and increases their visibility or influence, this affects their behavior and they tend to act under impulsive tendencies (Kacen \& Lee, 2002).

There are still other instruments to measure impulsiveness in the field of consumption (e.g., Puri, 1996; Verplanken \& Herabadi, 2001; Weun, Jones, \& Beatty, 1998; Youn \& Faber, 2000). They include the Impulsive Buying Tendency Scale by Verplanken and Herabadi (2001) and Consumer Impulsiveness Scale (CIS) by Puri (1996).

Verplanken and Herabadi (2001) developed a general measure of impulsive buying tendency including cognitive aspects and lack of planning as well as affective aspects and emotional responses after impulse buying behavior. On the other hand, the instrument developed by Puri (1996) offers adjectives aimed at measuring consumer impulsiveness, addressing the situational importance of the costs and benefits of the purchase, and individual values in relation to impulsiveness. In the study by Puri (1996), which generated the Consumer Impulsiveness Scale, the objective was to measure people's chronic values towards impulsiveness. This was the starting point of the creation of one of the first initiatives to evaluate affective (linked to hedonic pleasure) and cognitive (linked to self-control and prudence) components in the specific impulsiveness of the act of consumption.

Although there have been different attempts to conceptualize and measure impulse buying behavior, there is still a considerable gap with respect to impulse buying measures that present adequate evidence of validity for the Brazilian context. An adequate instrument for the Brazilian context is especially necessary in view of the large number of consumers who believe to be impulsive buyers, according to research carried out by the Credit Protection Service (SPC) and the National Confederation of Shopkeepers (CNDL) (SPC Brasil, 2015a).

Psico-USF, Bragança Paulista, v. 25, n. 1, p. 15-25, jan./mar. 2020 
In May 2015, the SPC Brazil survey (2015) found that $43 \%$ of supermarket purchases had been made on impulse. According to data from the same entities, the intensity and frequency can change according to several variables, but the habit is common to all Brazilians (SPC Brasil, 2015b) which shows that impulse buying is a reality of Brazilian consumers that deserves be psychologically studied. Considering that impulse buying is a behavior exercised by a large part of the Brazilian population, and that it is known that increasing the frequency of such behavior can lead to compulsive buying (Vohs \& Faber, 2007), seeking validity evidences of an instrument to measure this behavior becomes paramount.

Thus, this study was designed to find validity evidences, based on the internal structure and relations with other variables, for the Rook and Fisher's Buying Impulsiveness Scale (1995) in the Brazilian context. This scale has been used in different contexts (e.g., in Argentina - Revilla et al., 2013; in Turkey - Shehzadi et al., 2016; in the United States - Sun et al., 2004; in Hong Kong - Thompson \& Prendergast, 2015). The versions already translated to other languages have corroborated the instrument's one-factor structure and presented adequate indices of internal consistency (e.g., Revilla et al., 2013; Shehzadi et al., 2016). Considering the importance of this scale in the international context, it is believed that its use in Brazil would facilitate the exchange of information on the theme and comparisons between countries. Moreover, a scale that is tailored for the Brazilian context may foster research to understand the phenomenon itself and its relationships with other variables. Although the instrument of Rook and Fisher (1995) has already been translated and used in Brazil by Santini and Espartel (2008), no evidence of validity for the national context has yet been presented.

\section{Method}

\section{Participants}

A total of 1,296 Brazilians with a mean age of 35.8 years $(S D=12.8)$ participated in this study, of which $74 \%$ were women. The sample had people from all states of the country, with $52.85 \%$ of respondents from the Southeast region; $17.82 \%$ from the Northeast; $17.36 \%$ from the South; $8.72 \%$ from the Central-west; and $3.2 \%$ from the North. As for schooling, 3.1\% had primary education, $9.6 \%$ high school, $45.5 \%$ higher education, and $41.7 \%$ post-graduation. Of the total number of participants, $46.3 \%$ reported monthly income of up to $\mathrm{R} \$ 3,000.00 ; 21.7 \%$ between $\mathrm{R} \$$ $3,001.00$ and $\mathrm{R} \$ 5,000.00$; and $32.0 \%$ over $\mathrm{R} \$ 5,000.00$.

\section{Instruments}

An online questionnaire was made available at an Internet address. The questionnaire contained questions about sociodemographic aspects (gender, age, schooling, marital status, monthly income) and questions about purchasing habits, such as how many credit cards the person had and how often they were used; if the person prefers to buy alone or accompanied; and if the person usually make shopping lists. Besides these questions, the questionnaire contained the following instruments:

Buying Impulsiveness Scale (Rook \& Fisher, 1995; translated by Santini \& Espartel, 2008). The version translated into Portuguese by Santini and Espartel (2008) of the instrument of Rook and Fisher (1995) was used. In the present study, evidences of validity and reliability indicators of the Brazilian version of the instrument are presented. The scale proposes to measure a single factor regarding impulse buying tendency. The instrument contains nine items in the form of affirmative sentences. Thus, the participants can respond about the extent to which they agree with each statement on a seven-point scale. The higher the score, the higher is the impulse buying level. In the original version of Rook and Fisher (1995), the instrument had an alpha coefficient of .88 .

Scale of consumer susceptibility to interpersonal influence (Bearden, Netemeyer, \& Teel, 1989; adapted for Portuguese by Amaral, Aquino, Souza, Diogo, \& Lins, 2017). This scale is intended to measure a person's tendency to be susceptible to the influence of other people on buying activities. The instrument has 12 items and two factors: Normative (nine items) and Informational (three items). The Normative factor refers to a person's tendency to buy based on the expectations of others, and the Informational factor refers to the tendency for individuals to obtain information from others in order to carry out their purchases. The items are presented in affirmative sentences for participants to inform the extent to which they agree with each statement on a seven-point scale. The higher the scores, the greater is the tendency to change their buying choices because of social pressures. In the study by Amaral et al., the alpha coefficient for the Normative dimension was .87 , and for the Informational dimension was .70. 
Consumer impulsiveness scale (CIS) (Puri, 1996; translated by Santini, 2013). This instrument proposes to measure consumer impulsiveness traits. The CIS consists of 12 adjectives followed by a sevenpoint scale for respondents to indicate how closely each adjective listed properly describes them. The scale has two factors: Prudence (seven items), with items covering planning and deliberation characteristics, for example; and Hedonic (five items), with items evaluating pleasure in impulse buying, such as impulsiveness and lack of control, for example. The higher the scores on the Prudence factor, the greater is the control over impulsiveness in purchases; the higher the scores on the Hedonic factor, the less is the control over impulsiveness and the greater the pleasure to buy. In the present study, the alpha coefficient for the Hedonic factor was .63 , and for the Prudence factor was .70.

Iowa-Netherlands Comparison Orientation scale (INCOM) (Gibbons \& Buunk, 1999; adapted for Portuguese by Lins, Campos, Leite, Carvalho, Cardoso, \& Natividade, 2016). This scale proposes to measure the individual differences in orientation for social comparison through two factors: Abilities and Opinions. The Abilities factor has six items and consists in the comparison of skills and abilities; the Opinion factor has five items and consists in the comparison of feelings and thoughts. The INCOM consists of 11 items in the form of sentences that the participants can inform the extent to which they agree with each of them, on a seven-point scale. The higher the scores, the greater is the tendency to social comparison. In the study by Lins et al., (2016), the following alpha coefficients were found: Abilities, alpha coefficient of .89; Opinions, alpha coefficient of .82 .

\section{Procedures}

Participants were recruited by emails and invitations on social networks. The invitations explained the research and provided the link to access the questionnaire, which went online for twelve months, between April 2014 and April 2015. The time to complete the questionnaire was approximately 45 minutes. Free and Informed Consent Form was presented on the first page of the questionnaire, complying with all directives and norms regulating research involving human beings in Brazil. The form was arranged so as to not allow for missing answers in the items, and there was, therefore, no need to perform transformations of missing cases. Only the questions relevant to the present study were described in this section. The project was approved by the Human Research Ethics Committee of the Pontifical Catholic University of Rio de Janeiro under protocol number 2014-06.

\section{Results}

In order to obtain evidence of validity based on the instrument's structure, a confirmatory factorial analysis was performed, since the original instrument proved to have a one-factor structure. A covariance matrix was used as basis for calculation of parameters, and the Maximum Likelihood algorithm was chosen, and a one-factor model was specified. The AMOS 16 software was used in this analysis and the following recommended fitness indices were evaluated (see Byrne, 2009): ratio between chi-square and degrees of freedom; Goodnessof-Fit Index (GFI); Adjusted Goodness-of-Fit Index (AGFI); Normed Fit Index (NFI); Tucker-Lewis Index (TLI); Comparative Fit Index (CFI); Root Mean Square Error of Aproximation (RMSEA); Consistent Akaike Information Criterion (CAIC). Results can be seen in Table 1.

The goodness-of-fit indices suggested the specification of models with correlated item errors. Better fitted indices were observed in the model in which the errors of two pairs of items were correlated. Although the data presented a better fit in the model with the correlated errors, the goodness-of-fit indices without correlated errors were already reasonable (see Ho, 2014). In addition, the instrument presented alpha coefficient (Cronbach, 1951) and total omega coefficient (McDonald, 1999) of .88, thus showing a satisfactory internal consistency index (see Nunnally, 1978).

Although the Maximum Likelihood method may prove adequate in conditions of absence of multivariate normality (Chou, Bentler, \& Satorra, 1991), factorial analyses were also performed with a robust method (Satorra \& Bentler, 1994). For this, the R software (Venables, Smith, \& R Core Team, 2018) and the Latent Variable Analysis (Lavaan) statistical package (Rossel, 2012) were used. The results found with the robust method were similar to the one previously found. For example, $\chi^{2}(25, N=1296)=139.9 ; p<.001 ; \chi^{2} / g l=$ 5,$60 ; \mathrm{TLI}=.96$; CFI $=.97$ and RMSEA $=.060$.

Correlations between impulse buying, consumer impulsiveness traits, social influence, income and age were tested in the search for evidence of validity based on relationships with other variables. Table 2 shows the Pearson correlation coefficients found. There were significant positive relations between impulse buying and the Affective dimension of impulsiveness, $r$ (1296) $=$ 
.54 , and the Normative dimension of social influence, $r(1296)=.23$; and a negative and significant relation between impulse buying and the Cognition factor of consumer impulsiveness, $r(1296)=-.32$.
The Student's t-test was also used to test the power of the instrument to discriminate groups of people according to impulse buying behaviors. It was verified that the instrument was able to differentiate people who

Table 1.

Indices of the Models Tested from the Confirmatory Factorial Analysis

\begin{tabular}{cccc}
\hline & \multicolumn{3}{c}{ Models } \\
\cline { 2 - 4 }$\chi^{2}$ & Initial & Correlated Errors A & Correlated Errors B \\
$\mathrm{n}$ df & 325.7 & 221.9 & 173.3 \\
$p$ & 27 & 26 & 25 \\
$\chi^{2} / \mathrm{gl}$ & $<.001$ & $<.001$ & $<.001$ \\
$\mathrm{GFI}$ & 12.1 & 8.5 & 6.9 \\
$\mathrm{AGFI}$ & .94 & .96 & .97 \\
NFI & .91 & .93 & .95 \\
TLI & .94 & .95 & .97 \\
CFI & .93 & .95 & .96 \\
RMSEA & 0.94 & .96 & .97 \\
$90 \%$ CI RMSE & .092 & .076 & .068 \\
CAIC & $.084-.102$ & $.067-.086$ & $.058-.077$ \\
\hline
\end{tabular}

Note. Initial - Single-factor model composed of nine items regarding impulse buying. Correlated Errors A - Model correlating errors of items 1 and 2. Correlated Errors B - Model correlating errors of items 1 and 2 and correlating errors of items 5 and $7 \cdot \chi^{2}-$ chi-square; df - degrees of freedom; $\chi^{2} / \mathrm{gl}$ - ratio between chi-square and degrees of freedom; GFI - Goodness-of-Fit Index; AGFI - Adjusted Goodness-of-Fit Index; NFI - Normed Fit Index; TLI - Tucker-Lewis Index; CFI - Comparative Fit Index; RMSEA - Root Mean Square Error of Approximation; IC 90\% RMSEA - 90\% confidence interval; CAIC - Consistent Akaike Information Criterion.

Table 2.

Relationship Between Impulse Buying and Other Investigated Variables

\begin{tabular}{lcccccccccc}
\hline & $M$ & $S D$ & 1 & 2 & 3 & 4 & 5 & 6 & 7 & 8 \\
\hline Impulse Buying & 2.95 & 1.27 & $(.87)$ & & & & & & & \\
CIS - Hedonic factor & 3.07 & 1.12 & $.54^{* *}$ & $(.63)$ & & & & & \\
CIS - Prudence factor & 5.10 & 1.00 & $-.32^{* *}$ & $-.30^{* *}$ & $(.77)$ & & & & \\
Social Influence - & 1.98 & 1.09 & $.23^{* *}$ & $.16^{* *}$ & $-.08^{* *}$ & $(.87)$ & & & \\
Normative Factor & & & & & & & & & & \\
Social Influence - & 3.77 & 1.37 & -.02 & .03 & $.06^{*}$ & $.43^{* *}$ & $(.68)$ & & & \\
Informational Factor & & & & & & & & & & \\
INCOM - Opinions & 5.00 & 1.17 & $.11^{* *}$ & $.14^{* *}$ & -.02 & $.21^{* *}$ & $.38^{* *}$ & $(.82)$ & & \\
INCOM - Abilities & 4.07 & 1.52 & $.16^{* *}$ & $.17^{* *}$ & -.03 & $.35^{* *}$ & $.32^{* *}$ & $.59^{* *}$ & $(.89)$ & \\
Age & 35.8 & 12.9 & .01 & $-.06^{*}$ & $.08^{* *}$ & -.03 & -.04 & .002 & $-.07^{*}$ & - \\
Monthly income & 3.83 & 1.86 & -.02 & $-.09^{* *}$ & $.15^{* *}$ & .02 & .03 & -.01 & $-.08^{* *}$ & $.09^{* *}$ \\
\hline
\end{tabular}

Note. $* * p<.01 ; * p<.05 . N=1296$. CIS - Consumer impulsiveness scale. INCOM - Iowa-Netherlands comparison orientation scale. The alpha coefficients found in this study are in brackets on the main diagonal. 
make shopping lists $(M=2.77, S D=1.14)$ from those who $\operatorname{did} \operatorname{not}(M=3.27, S D=1.40), t(1294)=6.62$; $p<0.001 ; d=0.39$; and people who preferred to go shopping alone $(\mathrm{M}=3.05, S D=1.35)$ from those who preferred to go shopping accompanied by other people $(M=2.79, S D=1.09), t(1294)=3.80 ; p<.001 ; d=$ 0.21 . Finally, it was observed that women $(M=3.04$, $S D=1.30)$ presented higher impulse buying levels than males $(M=2.67, S D=1.13), t(1294)=-5.10 ; p<.001$; $d=0.30$. The magnitude of the effect was calculated according to the coefficient proposed by Cohen (1988).

\section{Discussion}

The objective of this study was to find evidence of validity of the Buying Impulsiveness Scale proposed by Rook and Fisher (1995) for the Brazilian context. The used a version of the scale translated into Portuguese by Santini and Espartel (2008). Initially, the adequacy of the one-factor structure for the instrument it was verified in accordance with the original study and the versions adapted for other cultures (e.g., Olsen, Tudoran, Honkanen, \& Verplanken, 2010; Revilla et al., 2013; Shehzadi et al., 2016). The indices showing the goodness-of-fit of the data to the model, such as the GFI, NFI and CFI, were above .90, which may be considered adequate (see Ho, 2014). In the model without correlating errors, the RMSEA showed a value slightly above the recommended one. However, in models with correlated errors, all the indices, including RMSEA, were better. The instrument also presented adequate indices of internal consistency, indicating a satisfactory reliability (see Cronbach, 1951; McDonald, 1999, Nunnally, 1978).

In the search for other evidences of validity, the relationships between impulse buying and other variables were tested. There were significant correlations between impulse buying, measured by the Buying Impulsiveness Scale, and impulsiveness traits in purchase situations measured by the other test developed by Puri (1996). The results support Rook and Fisher's (1995) theory, showing significant relations with both aspects of the CIS (Puri, 1996), which were positive with the factor related to pleasure to buy on impulse, and negative with the factor related to control while shopping.

These results corroborate the theory that impulse buying is often characterized by lack of reflection and can be interpreted as a momentary failure of self-control. Therefore, although there is the same limitation inherent in one-dimensional and self-applied instruments with few items, the instrument covers both the cognitive and affective aspects of impulse buying, and the mechanisms used to measure the trait of impulse buying. Rook and Fisher's (1995) Buying Impulsiveness Scale can be considered the first to measure impulsiveness in the context of purchases with the aim of measuring the construct itself, and not only adjectivizing personal characteristics of the consumer (as in the instrument by Puri, 1996).

Some correlations consonant with earlier studies on impulse buying and social influence were found. The results suggest that when consumers believe that impulse buying is socially acceptable, they act under impulsive tendencies (as highlighted by Kacen \& Lee, 2002). Rook and Fisher (1995) suggested that social influences moderate the impulse buying behavior, and have the potential to enhance or restrain this behavior by stimulating or constraining it through social norms. The theoretical model proposed by Taute and McQuitty (2004) considers that social norms cause an impact on the individual's level of impulsiveness. Findings by Lin and Chen (2012) also reveal that the greater the susceptibility to social influences, the greater is the tendency to buy on impulse.

The relationship between impulse buying and the normative factor of social influence is based on the theory that this construct is a potentiator of impulsiveness in purchases (Bearden et al., 1989; Puri, 1996; Taute \& McQuitty, 2004). Consumer susceptibility to social influence can be defined as the need to identify or enhance one's image before others through the acquisition and use of products and brands (Santini, Ladeira, \& Araujo, 2015). The willingness to conform personal purchasing decisions to the expectations of others and the tendency to learn about products and services by observing others or seeking information from others was corroborated by the significant, albeit low, relationships between the normative factor of Social Influence and two dimensions of Social Comparison: Skills and Opinions.

It is understood that the tendency of impulse buyers to seek the approval of others and the propensity for conformity was corroborated in the correlational analyses carried out in this study. As theorized by Rook and Fisher (1995), if the individual perceives that his buying impulse is socially appropriate, there is a greater probability that he will positively evaluate the purchase. In this sense, it would be expected to find higher levels of impulsiveness in purchases among people who prefer to go shopping along with other people, compared 
to those who prefer to go alone. The instrument was able to differentiate these groups of people, but an interesting fact stood out: people who preferred to go shopping alone had higher impulse buying levels than those who preferred to go shopping accompanied by other people. That indicates that if the buyer is not accompanied in the shop environment, there is a greater propensity to give in to buying impulses than if accompanied. A market survey also pointed to this same trend that when people are on their own, they buy more impulsively (see Folha de S.Paulo, 2012). This can be due to the fact that the consumer tends to have his inhibitions reduced when he is alone, allowing the concretization of his impulses in acts of purchase without reflecting so much on social norms.

Considering that the visibility of the purchase (i.e. how much an impulse purchase is seen by others) also affects the consumer's behavior (Fisher \& Price, 1992). And the type of company and the cohesion among the people of the group in the moment of the purchase can influence the behavior of the consumer. For example, the presence of peers at the time of purchase increases the urge to buy impulsively, while the presence of family members decreases this tendency (Luo, 2005). This is intensified when the group (peers or family members) is cohesive and when the participants are susceptible to social influence (Lins, Poeschl, \& Eberhardt, 2016). Future studies can jointly ponder these moderating variables in their analyses.

Regarding age and income, no significant correlations were found between these variables and impulse buying. Results of previous studies have indicated age group as negatively associated with impulse buying (Amo, Holmes, \& Kenelson, 2013; Kacen \& Lee, 2002). It is reasonable to expect a negative correlation between age and impulse buying because younger consumers demand more consumption, tend to be more materialistic, and seek self-affirmation and social insertion through consumption (Niu \& Wang, 2009; Santini, Ladeira, Vieira, Araújo, \& Sampaio, 2018; Yang, De Wang, \& Niu, 2008).

The correlation between impulse buying and income was not significant in the present study. Considering that income can be a factor that facilitates impulse buying (Peñaloza, Portela, Gerhard, \& Quezado, 2018; Santini, Ladeira, Vieira, Araújo, \& Sampaio, 2018), it would be reasonable to find a correlation between them in the present sample. It is noteworthy that the average income declared by more than $50 \%$ of participants was greater than $R \$ 2,700.00$, and that other studies have suggested a positive relationship between income and impulse buying (Amo, Holmes, \& Kenelson, 2013). Thus, it is understood that it would be interesting to examine other variables that could act as moderators among age, income and impulse buying.

The results showed that the scale was also able to differentiate people who make shopping lists from those who do not. The difference indicates that consumers who make plans more frequently, who make a roadmap of what they need to buy, tend to have lower levels of impulse buying than those who do not organize a list. This characteristic may be related not only to a habit but also to a personality trait. One of the five personality factors of the Big Five model, the Realization, is characterized by the individual's tendency to be disciplined and organized (Natividade \& Hutz, 2015). Aquino, Lins and Natividade (2017) found a negative correlation between the Realization factor and impulse buying. The results found in the current study showed that people who do not plan shopping with lists are more likely to buy impulsively. This gives allows the assumption that by not making a list these people tend to lose more time at the place of purchase and thus may be more likely to find products that were not in their plans to buy, and make more impulse purchases.

The instrument was also in agreement with the literature regarding gender differences in impulse buying. The tendency of women to be more impulsive than men in buying behavior was confirmed in this study, indicating that gender has an effect on the impulsiveness in purchases, in line with previous studies (Coley \& Burgess, 2003; Dittmar, 2005; Dittmar, Beattie, \& Friese, 1995; Lins \& Pereira, 2011; Priyanka \& Rooble, 2012; Zhang, Prybutok, \& Strutton, 2007). Economic and social factors are not the only factors that affect the consumers' responses to their buying impulses. Other elements involved in the impulsiveness observed in buying behaviors include the normative influence, through which the individual recognizes and evaluates social repercussions of his behavior.

\section{Final considerations}

Considering the sample used in this study, which consisted of adults aged 18 to 65 years from all states of the Brazilian federation, the results indicate that the scale has sufficient evidence of validity to be used in the national context. However, although the sample used was large, the result should be interpreted with 
caution, not only for the surplus of women, but also for the socioeconomic characteristics of the sample. More than half of the participants declared a monthly income above three national minimum wages and $41.7 \%$ of the people had post-graduate degrees. Therefore, the validity evidences found are appropriate for samples with such characteristics.

Although the instrument encompasses both the cognitive and affective aspects of impulse buying, and the mechanisms used to measure impulse buying, there is a limitation that is inherent of self-applied instruments with few items. Furthermore, in addition to the normative influence addressed in this study, it is proposed that future studies may consider other moderating variables in their analyses. For example, a stronger correlation was observed between impulse buying and pleasure generated by the purchase (gratification pursuit) as measured by the Hedonic factor of the Consumer Impulsiveness scale, which opens new avenues for future investigations to further the in-depth investigation of these relationships. Also, the presence of peers or family members at the moment of purchase could be considered (e.g., Luo, 2005) and whether such visibility would affect the behavior (e.g., Fisher \& Price, 1992).

Considering such limitations of the study, it is advisable to conduct other empirical investigations on impulse buying to improve and consolidate the already existing scales and models. Future investigations of whether the observations in controlled situations are representative of what happens in daily life (see Brewer \& Crano, 2014) are also encouraged. They would advance the evidence of ecological validity, testing the extent to which the Buying Impulsiveness Scale measures situational factors of the field.

\section{References}

Amaral, R., Aquino, S., Souza, M., Diogo, C., \& Lins, S. (2017). Adaptação e validação da escala de influência social nas compras no contexto brasileiro. In $8^{\circ}$ Congresso Brasileiro de Avaliação Psicológica. Florianópolis, SC, Brasil. doi: 10.13140/ RG.2.2.31393.20320

Amos, C., Holmes, G. R., \& Keneson, W. C. (2014). A Meta-analysis of consumer impulse buying. Journal of Retailing and Consumer Services, (21)2, 86-97. doi: 10.1016/j.jretconser.2013.11.004

Aquino, S. D., Lins, S. L. B., \& Natividade, J. C. (2017). Sua personalidade vai ao shopping? Relações entre personalidade e compra por impulso. Pôster apresentado na $47^{a}$ Reunião Anual da Sociedade Brasileira de Psicologia, São Paulo, SP.

Arnould, E. J., Price, L. L. L., \& Zinkhan, G. M. (2004). Consumers ( $2^{\text {nd }} \mathrm{ed}$.). Boston: McGraw-Hill/Irwin.

Bearden, W. O., Netemeyer, R. G., \& Teel, J. E. (1989). Measurement of consumer susceptibility to interpersonal influence. The Journal of Consumer Research, 15(4), 473-481. doi: 10.1086/209186

Brewer, M. B., \& Crano, W. D. (2014). Research design and issues of validity. In H. T. Reis \& C. M. Judd (Ed.), Handbook of Research Methods in Social and Personality Psychology: Second Edition (pp. 11-27). New York: Cambridge University Press.

Byrne, B. M. (2009). Structural Equation Modeling with EQS: Basic Concepts, Applications, and Programming. Second Edition. Mahwah: Lawrence Erlbaum Associates.

Chou, C.-p., Bentler, P. M., \& Satorra, A. (1991). Scaled test statistics and robust standard errors for non-normal data in covariance structure analysis: A Monte Carlo study. British Journal of Mathematical and Statistical Psychology, 44(2), 347-357. doi: 10.1111/j.2044-8317.1991.tb00966.x

Cohen, J. (1988). Statistical power analysis for the behavioral sciences (2 ${ }^{\text {nd }}$ ed.). New York: Lawrence Erlbaum Associates.

Coley,A., \& Burgess, B. (2003). Genderdifferencesin cognitive and affective impulse buying. Journal of Fashion Marketing and Management: An International Journal, 7(3), 282-295. doi: 10.1108/13612020310484834

Cronbach, L. J. (1951). Coefficient alpha and the internal structure of tests. Psychometrika, 16(3), 297-334. doi: 10.1007/BF02310555

Dittmar, H. (2005). Compulsive buying - a growing concern? An examination of gender, age, and endorsement of materialistic values as predictors. British Journal of Psychology, 96(4), 467-491. doi: 10.1348/000712605X53533

Dittmar, H., Beattie, J., \& Friese, S. (1995). Gender identity and material symbols: Objects and decision considerations in impulse purchases. Journal of Economic Psychology, 16(3), 491-511. doi: 10.1016/0167-4870(95)00023-H

Psico-USF, Bragança Paulista, v. 25, n. 1, p. 15-25, jan./mar. 2020 
Farina, M., Perez, C., \& Bastos, D. (2006). Psicodinâmica das Cores em Comunicaşão (5 ed). São Paulo: Edgard Blucher.

Fisher, R. J., \& Price, L. L. (1992). An investigation into the social context of early adoption behavior. Journal of Consumer Research, 19(4), 477-486. doi: $10.1086 / 209317$

Folha de S.Paulo. (2012, Agosto 30). Brasileiros preferem fazer compras sozinhos, indica estudo. Folha de S.Paulo. Retrieved from http://classificados. folha.uol.com.br/negocios/2012/08/1145772-brasileiros-preferem-fazer-compras-sozinhos-indica-estudo.shtml

Garðarsdóttir, R. B., \& Dittmar, H. (2012). The relationship of materialism to debt and financial well-being: The case of Iceland's perceived prosperity. Journal of Economic Psychology, 33(3), 471-481. doi: 10.1016/j.joep.2011.12.008

Ho, R. (2014). Multivariate Data Analysis with IBM SPSS. ( $2^{\circ}$ ed). Boca Raton: CRC Press.

Hoyer, W. D., MacInnis, D. J., \& Pieters, R. (2016). Consumer Behavior $\left(7^{\circ} \mathrm{ed}\right)$. Boston: Cengage Learning Nacional.

Kacen, J. J., \& Lee, J. A. (2002). The influence of culture on consumer impulsive buying behavior. Journal of Consumer Psychology, 12(2), 163-176. doi: 10.1207/ S15327663JCP1202_08

Lin, Y.-H., \& Chen, C.-Y. (2012). Adolescents' impulse buying: Susceptibility to interpersonal influence and fear of negative evaluation. Social Behavior and Personality, 40(3), 353-358. doi: 10.2224/ sbp.2012.40.3.353

Lins, S. L. B., Campos, M., Leite, A. C., Carvalho, C. L., Cardoso, S., \& Natividade, J. C. (2016). Evidências de validade da escala de orientação para a comparação social (INCOM) para o contexto de adolescentes portugueses. Revista da Associação Portuguesa de Psicologia, 30(1), 1-14. doi: 10.17575/ rpsicol.v30i1.1034

Lins, S. L. B., \& Pereira, R. de C. de F. (2011). Comprou sem querer? Entenda o porquê! Revista Brasileira de Gestão de Negócios, 13(41), 376-395. doi: 10.13140/ RG.2.2.12531.12326

Lins, S. L. B., Poeschl, G., \& Eberhardt, A. (2016). Identificando os factores de influência da compra por impulso em adolescentes portugueses. Análise Psicológica, 34(2), 147-163. doi: 10.14417/ap.920

Luo, X. (2005). How does shopping with others influence impulsive purchasing? Journal of Consumer Psychology, 15(4), 288-294. doi: 10.1207/ s15327663jcp1504_3

McDonald, R. P. (1999). Test theory: A unified treatment. Mahwah, NJ: Lawrence Erlbaum.

Mangleburg, T. F., Doney, P. M., \& Bristol, T. (2004). Shopping with friends and teens' susceptibility to peer influence. Journal of Retailing, 80(2), 101-116. doi: 10.1016/j.jretai.2004.04.005

Masouleh, S. E., Pazhang, M., \& Moradi, J. S. (2012). What is impulse buying? An analytical network processing framework for prioritizing factors affecting impulse buying. Management Science Letters, 2(4), 1053-1064. doi: 10.5267/j.msl.2012.03.016

Natividade, J. C., \& Hutz, C. S. (2015). Escala reduzida de descritores dos cinco grandes fatores de personalidade: prós e contras. Psico (PUCRS), 46(1), 79-89. doi: 10.15448/1980-8623.2015.1.16901

Niu, H. J., \& Wang, Y. D. (2009). Work experience effect on idolatry and the impulsive buying tendencies of adolescents. Adolescence, (44)173, 233-243.

Nunnally, J. C. (1978). Psychometric Theory (2nd ed.). Nova Iorque: McGraw Hill.

Olsen, S. O., Tudoran, A. A., Honkanen, P., \& Verplanken, B. (2010). Differences and similarities between impulse buying and variety seeking: A personality-based perspective. Psychology \& Marketing, 30(6), 461-469. doi: 10.1002/mar

Peñaloza, V., Portela, M., S. O., Gerhard, F., \& Quezado, I. (2018). Representação social da compra por impulso por consumidores de baixa Renda. Consumer Behavior Review, 2(1), 1-12.

Podoshen, J. S., \& Andrzejewski, S. A. (2012). An examination of the relationship between materialism, conspicuous consumption, impulse buying, and brand loyalty. Journal of Marketing Theory and Practice, 20(3), 319-334. doi: 10.2753/ MTP1069-6679200306

Priyanka, V., \& Rooble, V. (2012). An on-field-survey of the impulse buying behaviour of consumers in consumer non durable sectors in the retail outlets 
in the city of Indore, India. Research Journal of $M a$ nagement Sciences, 1(4), 2319-1171.

Puri, R. (1996). Measuring and modifying consumer impulsiveness: A cost-benefit accessibility framework. Journal of Consumer Psychology, 5(2), 87-113. doi: 10.1207/s15327663jcp0502_01

Revilla, R. G., Acosta, C., \& Reyna, C. (2013). Estudios de validez y confiabilidad de la escala de compra impulsiva en jóvenes y adultos de la ciudad de Córdoba, Argentina. Ciencias Psicológicas, 7(2), 133-142.

Rook, D. W., \& Fisher, R. J. (1995). Normative influences on impulsive buying behavior. Journal of Consumer Research, 22(3), 305. doi: 10.1086/209452

Rossel, Y. (2012). lavaan: An R package for structural equation modeling. Journal of Statistical Software, 48(2), 1-36. doi: 10.18637/jss.v048.i02

Sánchez, F. J. S., \& Schmidt, T. H. (2004). Un análisis del comportamiento de impulsividad del consumidor y propuesta de una escala para medir el comportamiento impulsivo. Spanish Journal of Marketing - ESIC (SJME), 480(4), 457-482.

Santini, F. D. O. (2008). Promoção de distribuição de prêmios e sua influência na compra por impulso e nas intençôes de recompra (Dissertação de mestrado não publicada). Pontifícia Universidade Católica do Rio Grande do Sul, Brasil.

Santini, F. D. O. (2013). Uma análise da influência da promoção de vendas de desconto na intenção de compra do consumidor e os efeitos moderadores da atratividade (Tese de doutorado não publicada). Pontifícia Universidade Católica do Rio Grande do Sul, Brasil.

Santini, F. D. O., Ladeira, W. J., \& Araújo, C. F. (2015). Antecedentes e consequentes da influência interpessoal: uma meta-análise da escala. In VI Encontro de Marketing da ANPAD, Gramado, RS, Brasil.

Santini, F. D. O., Ladeira, W. J., Vieira, V. A., Araújo, C. F., \& Sampaio, C. H. (2018). Uma meta-análise sobre os construtos antecedentes e consequentes do materialismo. RAUSP Management Journal, (19)66, 538-556. doi: 10.1108/RAUSP-07-2018-0037.

Shehzadi, K., Ahmad-ur-Rehman, M., Mehmood Cheema, A., \& Ahkam, A. (2016). Impact of personality traits on compulsive buying behavior: Mediating role of impulsive buying. Journal of Service Science and Management, 9(5), 416-432. doi: 10.4236/ jssm.2016.95046
Serviço de Proteção ao Crédito Brasil. SPC Brasil. (2015a). O crédito e as compras por impulso. Retrieved from https://www.spcbrasil.org.br/imprensa/ noticia/116

Serviço de Proteção ao Crédito Brasil. SPC Brasil. (2015b). Retrato do consumo impulsivo no Brasil. Retrieved from https://www.spcbrasil.org.br/imprensa/ noticia/98

Sun, T., Wu, G., \& Youn, S. (2004). Psychological antecedents of impulsive and compulsive buying: A hierarchical perspective. In The Proceedings of the Society for Consumer Psychology 2004 winter conferencce. San Francisco, CA, USA.

Taute, H., \& McQuitty, S. (2004). Feeling Good! Doing Good! An exploratory look at the impulsive purchase of the social good. Journal of Marketing Theory and Practice, 12(2), 16-27. doi: 10.2307/40470134

Thompson, E. R., \& Prendergast, G. P. (2015). The influence of trait affect and the five-factor personality model on impulse buying. Personality and Individual Differences, 76, 216-221. doi: 10.1016/J. PAID.2014.12.025

Venables, W. N., Smith, D. M., \& R Core Team. (2018). An Introduction to $\mathrm{R}$. The $\mathrm{R}$ Foundation for Statistical Computing. Retrieved from https://cran.r-project. org/doc/manuals/R-intro.pdf

Verplanken, B., \& Herabadi, A. (2001). Individual differences in impulse buying tendency: Feeling and no thinking. European Journal of Personality, 15(S1), S71-S83. doi: 10.1002/per.423

Vohs, K. D., \& Faber, R. J. (2007). Spent resources: Self-regulatory resource availability affects impulse buying. Journal of Consumer Research, 33(4), 537-547. doi: $10.1086 / 510228$

Weun, S., Jones, M. A., \& Beatty, S. E. (1998). Development and validation of the impulse buying tendency scale. Psychological Reports, 82(3), 11231133. doi: $10.2466 / \mathrm{pr} 0.1998 .82 .3 \mathrm{c} .1123$

Yang, C., De Wang, Y., \& Niu, H.J. (2008). The effects of idolatry and personality traits on impulse buying: An empirical study. International Journal of Management (25)4, 633-640. Retrieved from https://www. questia.com/library/journal/1P3-1623336551/ the-effects-of-idolatry-andpersonality-traits-on

Youn, S., \& Faber, R. J. (2000). Impulse buying: Its relation to personality traits and cues. Advances in 
Consumer Research, 27(1), 179-185. Retrieved from http://acrwebsite.org/volumes/8383/volumes/ v27/NA-27

Zhang, X., Prybutok, V., \& Strutton, D. (2007). Modeling influences on impulse purchasing behaviors during online marketing transactions. The Journal of Marketing Theory and Practice, 15(1), 79-89. doi: 10.2753/MTP1069-6679150106

Recebido em: 27/01/2018 Reformulado em: 30/10/2018

Aceito: 08/01/2019

About the authors:

Sibele Dias de Aquino - PhD candidate student at the Graduate Program in Psychology, Pontifical Catholic University of Rio de Janeiro. Researcher at the Laboratory of Research in Social Psychology (L2PS) of the Pontifical Catholic University of Rio de Janeiro. Master in Psychology (Social Cognitive). Postgraduate degree in Business Communication and in Marketing.

ORCID: https://orcid.org/0000-0003-1391-0911

E-mail: sibele.aquino@gmail.com

Jean C. Natividade - Professor of the Graduate Program in Psychology of the Pontifical Catholic University of Rio de Janeiro.

ORCID: https://orcid.org/0000-0002-3264-9352

E-mail: jeannatividade@gmail.com

Samuel Lincoln Bezerra Lins - Assistant Professor, Faculty of Psychology and Education Sciences of the University of Porto (FPCEUP), Portugal. Researcher of the Laboratory of Social Psychology (LPS) of the Center for Psychology at University of Porto (CPUP). Topics of interest: Consumer psychology, impulse buying, psychosocial aspects of consumer behavior.

ORCID: https://orcid.org/0000-0001-6824-4691

E-mail:samuellins@fpce.up.pt

Contact:

225 Marquês de São Vicente st., Gávea, Rio de Janeiro

Rio de Janeiro-RJ, Brazil

CEP: 22451-900 